\title{
Perbandingan Pengajaran Keterampilan Berbicara Bahasa Arab dan Bahasa Inggris Di Sekolah Tinggi Agama Islam Negeri Curup
}

\author{
Partomuan Harahap \\ Sekolah Tinggi Agama Islam Negeri (STAIN) Curup \\ partomuanh@yahoo.com
}

\begin{abstract}
Abstrak
Di STAIN Curup, perkembangan Bahasa Arab tidak secepat perkembangan Bahasa Inggris. Hal ini bisa dilihat dari penyelenggaraan seminar Internasional dengan menghadirkan nara sumber dari Negara Timur Tengah tapi bahasa yang digunakan dalam seminar adalah Bahasa Inggris. Minat mahasiswa masuk ke Program Studi Tadris Bahasa Inggris lebih tinggi dibandingkan ke Program Studi Pendidikan Bahasa Arab. Mereka menganggap Bahasa Inggris lebih mudah dibandingkan bahasa Arab. Penelitian ini lebih memfokuskan pada pelaksanaan pengajaran Bahasa Arab dan Bahasa Inggris di STAIN Curup meliputi tujuan, materi, metode, media dan evaluasi. Metode penelitian yang digunakan adalah deskriptif kualitatif. Pengumpulan data menggunakan observasi, wawancara, dan dokumentasi. Teknik analisis data adalah reduksi data, display data, analisis data, dan narasi hasil analisis. Adapun hasil penelitian adalah pengajaran Muhadatsah dan pengajaran Speaking sama-sama melatih kemampuan mahasiswa dalam menggunakan bahasa-bahasa tersebut di dalam komunikasi dan interaksi dengan lawan bicara. Dalam pengajaran tidak hanya menggunakan buku sebagai referensi tapi juga memberikan kebebasan kepada mahasiswa dalam mempraktekkan bahasa asing dengan menemukan ide-ide baru diluar buku referensi yang dijadikan rujukan. Pembelajaran Muhadatsah dan Speaking di STAIN Curup bersifat Student Centris, dengan menyuguhkan metode yang bervariasi. Dalam pembelajaran Muhadatsah hanya memanfaatkan media audio, sedangkan dalam pembelajaran Speaking selain media audio juga menggunakan media audio-visual. Secara keseluruhan dapat dilihat bahwa pengajaran Muhadatsah dan Speaking sebagai pengajaran keterampilan berbicara bahasa Arab dan Inggris lebih ditekankan para proses pembelajarannya yaitu pembelajaran bukan menekankan sepenuhnya pada evaluasi.
\end{abstract}

Kata Kunci: Pengajaran, Keterampilan Berbicara, Bahasa Arab, Bahasa Inggris

Arabiyatuna : Jurnal Bahasa Arab, Vol. 1, No. 2, 2017

STAIN Curup | ISSN 2580-5053 (e), 2580-5045 (p)

Available online: http://journal.staincurup.ac.id/index.php/arabiyatuna 


\begin{abstract}
At STAIN Curup, Arabic development is not as fast as English development. This can be seen from the holding of international seminars by presenting speakers from Middle Eastern countries but the language used in the seminar is English. Students' interest in admission to the English Tadris Study Program is higher than that of the Arabic Education Studies Program. They consider English easier than Arabic. This research focuses more on the implementation of teaching Arabic and English in STAIN Curup covering objectives, materials, methods, media and evaluation. The research method used is descriptive qualitative. Data collection uses observation, interviews, and documentation. Data analysis techniques are data reduction, data display, data analysis, and narrative analysis results. The research result is Muhadatsah teaching and Speaking teaching equally train the students ability in using those languages in communication and interaction with the other person. In teaching not only using the book as a reference but also gives freedom to students in practicing foreign languages by finding new ideas outside reference books that are used as a reference. The learning of Muhadatsah and Speaking in STAIN Curup is Student Centris, by presenting various methods. In learning Muhadatsah only utilize audio media, while in learning Speaking in addition to audio media also use audio-visual media. Overall it can be seen that the teaching of Muhadatsah and Speaking as the teaching of Arabic and English speaking skills is emphasized by the learning process that is learning rather than emphasizing the evaluation.
\end{abstract}

Keywords: Teaching, Speaking Skills, Arabic, English

\title{
Pendahuluan
}

Bahasa adalah hal yang penting dalam kehidupan sosial manusia. Karena untuk berinteraksi manusia membutuhkan bahasa untuk berkomunikasi. Baik itu bahasa lisan maupun tulisan. Dengan adanya bahasa, manusia bisa menuangkan perasaan, ide dan gagasannya sehingga apa yang ada dalam pikiran dapat diketahui dan dimengerti oleh orang lain.

Dalam berkomunikasi manusia menggunakan beragam bahasa, baik itu Bahasa Indonesia, Bahasa Arab maupun Bahasa Inggris. Bahasa Arab adalah sebagai kunci pembuka ilmu pengetahuan keislaman. Sumber ajaran Islam yaitu Al-Qur'an berbahasa Arab membuat para muslim harus mempelajari Bahasa Arab ketika ingin mempelajari isi dari kitab suci Al-Qur'an tersebut. Begitu pula kitab-kitab klasik mengenai sejarah, keilmuan dan kebudayaan Islam terdahulu, banyak ditulis oleh para ilmuan Islam dalam Bahasa Arab. Sebagai bahasa ilmu pengetahuan, keberadaan Bahasa Arab telah diakui kedudukannya oleh lembaga Internasional, bahkan Perserikatan Bangsa-bangsa (PBB) telah membuat sebuah 
keputusan yang menetapkan Bahasa Arab sebagai salah satu bahasa resmi yang dipergunakan dalam lembaga Internasional serta lembaga-lembaga yang bernaung dibawahnya. Pada tahun 1973 untuk pertama kalinya Bahasa Arab dijadikan bahasa resmi dalam lingkungan PBB...Pemakaian Bahasa Arab sebagai salah satu bahasa resmi di PBB menempatkan Bahasa Arab untuk kegunaan menduduki peran sebagai salah satu alat komunikasi dalam hubungan diplomasi Internasional. ${ }^{1}$

Dengan demikian Bahasa Arab menjadi sangat penting artinya untuk bangsa Indonesia sebagai salah satu negara anggota PBB sekaligus sebagai negara yang mayoritas penduduknya beragama Islam. Adanya kepentingan tersebut, membuat Bahasa Arab menjadi menarik dan penting untuk dipelajari dan dikuasai.

Kemudian Bahasa Inggris, Bahasa ini tak kalah pentingnya dengan Bahasa Arab. Dewasa ini, perkembangan teknologi dan informasi yang begitu pesat tidak dapat melepaskan peranan Bahasa Inggris, begitu juga dalam dunia Internasional. Bahasa Inggris dijadikan bahasa resmi Internasional atau bahasa komunikasi dunia. Umat Islam juga harus mempelajarinya jika tidak ingin tersisih dari pergaulan dunia. Perkembangan Bahasa Inggris juga dapat dilihat dari metode pengajarannya yang telah diaplikasikan di negara-negara lain termasuk juga di Indonesia.

Melihat begitu urgensi kedua bahasa tersebut, maka memasukkan kedua bahasa tersebut dalam kurikulum pengajaran di sekolah-sekolah maupun Perguruan Tinggi adalah menjadi sebuah keharusan. Salah satu Perguruan Tinggi tersebut adalah STAIN Curup, yang akan melahirkan sarjana-sarjana yang nantinya akan bersaing bukan saja di tingkat nasional tapi juga internasional. Saat ini di STAIN Curup perkembangan Bahasa Arab tidak secepat perkembangan Bahasa Inggris. Hal ini bisa dilihat dari penyelenggaraan seminar Internasional dengan menghadirkan nara sumber yang notabenenya adalah dari Negara Timur Tengah tapi bahasa yang digunakan dalam seminar tersebut adalah Bahasa Inggris. Disamping itu juga bisa dilihat dari minat mahasiswa masuk ke Program Studi Tadris Bahasa Inggris (TBI) lebih banyak dibandingkan dengan ke Program Studi Pendidikan Bahasa Arab (PBA). Untuk saat ini mahasiswa Prodi TBI satu semester bisa mencapai 90 mahasiswa sedangkan di Prodi PBA hanya sekitar 20 mahasiswa untuk satu semester.

Kemudian ketika peneliti menyempatkan bertanya kepada mahasiswa, lebih mudah mana Bahasa Arab atau Bahasa Inggris ? mereka lebih memilih Bahasa Inggris, dengan alasan Bahasa Inggris menggunakan alphabet yang sudah lazim mereka kenal seperti layaknya Bahasa Indonesia, walaupun cara membaca

${ }^{1}$ Djuwairiah Dahlan, Metode Belajar Mengajar Bahasa Arab, (Surabaya: Al-Ihlas, 1992), h. 32-33. 
tidak persis sama. Sedangkan Bahasa Arab masih banyak yang kebingungan dengan huruf-huruf Arab yang membuat sukar untuk dihafalkan kosakatanya, hal ini juga dikarenakan latar belakang pendidikan mereka sebelum melanjutkan pendidikan di STAIN Curup, sebelumnya bukan dari Madrasah yang diajarkan Bahasa Arab tapi dari sekolah umum yang belum pernah belajar Bahasa Arab sama sekali, kalaupun ada itu sekedar mata pelajaran tambahan, dan tidak begitu membekas di pikiran mereka.

Salah satu aspek penting dalam pengajaran Bahasa (Bahasa Arab dan Bahasa Inggris) adalah aspek keterampilan untuk berbicara atau kemampuan berkomunikasi dengan bahasa tersebut. Sehingga pembelajaran bahasa tidak hanya untuk bisa mengerti, mengingat apa yang telah dibaca dan didengar, tetapi juga memperoleh kemampuan berbicara yaitu mampu menunagkan ide, gagasan dan perasaan dengan bahasa. Namun yang selama ini berlangsung adalah pengajaran tentang bahasa bukan pengajaran bahasa.

Fakta-fakta tersebut diatas, memberikan gambaran awal kepada peneliti bahwa pengajaran bahasa Arab dan Bahasa Inggris di STAIN Curup khususnya dalam pengajaran keterampilan berbahasa memiliki tingkat perkembangan yang berbeda. Namun penelitian yang akan peneliti lakukan ini tidak sampai sejauh mana hasil belajar yang telah dicapai dari pengajaran keterampilan berbahasa tersebut, karena hasil belajar bisa saja dipengaruhi oleh banyak hal seperti perbedaan minat, perbedaan latar belakang pendidikan, proses pelaksanaan pembelajan dan sebagainya. Penelitian ini akan lebih memfokuskan pada pelaksanaan pengajaran Bahasa Arab yaitu Mata Kuliah Muhadatsah dan Bahasa Inggris yaitu Mata Kuliah Speaking di STAIN Curup dan membandingkan pelaksanaan pengajaran antara kedua Mata Kuliah tersebut, meliputi tujuan, materi, metode, media dan evaluasi yang diterapkan pada masing-masing pembelajaran bahasa tersebut. Karena proses pembelajaran ini juga akan ikut mempengaruhi hasil yang akan dicapai nanti.

\section{Keterampilan Berbicara Bahasa Asing}

Menurut Effendy, keterampilan berbicara merupakan salah satu jenis keterampilan berbahasa yang ingin dicapai dalam pengajaran bahasa modern termasuk bahasa Arab. Berbicara merupakan sarana utama untuk membina saling pengertian, komunikasi timbal balik, dengan menggunakan bahasa sebagai medianya. ${ }^{2}$

Kemampuan atau keterampilan berbicara adalah kemampuan mengucapkan bunyi-bunyi artikulasi atau mengucapkan kata-kata untuk mengekspresikan, menyatakan, menyampaikan pikiran, gagasan, dan perasaan.

${ }^{2}$ Ahmad Fuad Effendy, Metodologi Pengajaran Bahasa Arab, (Malang : Misykat 2009), h.139 
Pendengar menerima informasi melalui rangkaian nada, tekanan, dan penempatan persendian. Jika komunikasi berlangsung secara tatap muka, ditambah lagi dengan gerak tangan dan air muka (mimik) pembicara. ${ }^{3}$

Jadi keterampilan berbicara bahasa asing dapat diartikan dengan kemampuan seseorang mengucapkan kalimat-kalimat bahasa asing untuk mengekspresikan, menyatakan serta menyampaikan pikiran, gagasan dan perasaan kepada orang lain.

\section{Pengajaran Keterampilan Berbicara Bahasa Arab}

\section{Tujuan Pengajaran Keterampilan Berbicara Bahasa Arab}

Menurut Ahmad Izzan tujuan pengajaran keterampilan bahasa Arab (Muhadatsah) adalah: ${ }^{4}$

a. Melatih lidah anak didik agar terbiasa dan fasih bercakap-cakap (berbicara) dalam bahasa Arab.

b. Terampil berbucara dalam bahasa Arab mengenai kejadian apa saja di dalam masyarakat dan dunia internasional yang diketahui.

c. Mampu menerjemahkan percakapan orang lain lewat telepon, radio, tv, tape recorder dan lain-lain.

d. Menumbuhkan rasa cinta dan menyenangi bahasa Arab dan Al-Qur'an sehingga timbul kemauan untuk belajar dan mendalaminya.

Menurut Anshor tujuan pembelajaran keterampilan berbicara bahasa Arab sebagai berikut :5

a. Siswa dapat melengkapi materi hiwar dengan kata-kata yang sesuai.

b. Siswa dapat menjawab pertanyaan-pertanyaan kandungan hiwar.

c. Siswa dapat memilih kata-kata yang tepat untuk melengkapi kalimat-kalimat yang disediakan yang berhubungan dengan hiwar.

d. Siswa dapat memilih suatu kata yang maknanya berbeda dengan tiga kata lainnya.

\section{Materi Pengajaran Keterampilan Berbicara Bahasa Arab}

Bahan Pelajaran atau materi adalah substansi yang akan disampaikan dalam proses belajar mengajar. ${ }^{6}$ Dalam kaitannya dengan pemilihan materi, guru

${ }^{3}$ Mukti, Pembinaan Kemampuan Berbicara Bahasa, (Jakarta : Erlangga, 1998), h. 81

4 Ahmad Izzan, Metodologi Pembelajaran Bahasa Arab, (Bandung: Humaniora, 2007), h. 87

${ }^{5}$ Anshor, Pengajaran Bahasa Arab. (Yogyakarka : Sukses offset, 2009), h. 8

${ }^{6}$ Syaiful Bahri Djamarah dan Aswan Zain, Strategi Belajar Mengajar, (Jakarta: Rineka Cipta, 2006) h. 43 
tidak mungkin memilih atas kemauannya sendiri, tetapi didasari oleh pedoman umum yang telah terumuskan oleh para ahli.

Bahan pelajaran harus dirumuskan dan disusun sedemikian rupa agar dapat menunjang tercapainya tujuan pengajaran. Dengan demikian harus terdapat hubungan yang harmonis dan sistematis antara tujuan yang hendak dicapai dengan materi pelajaran yang disediakan.

Adapun materi Muhadatsah pada umumnya berupa pola-pola kalimat yang terdiri dari beberapa kata yang tersusun dan mengandung faedah atau pengertian. Materi Muhadatsah tidak bisa disajikan seluruhnya kepada siswa, melainkan diajarkan secara bertahap dan perlu diadakan seleksi terhadap materi yang diajarkan, seleksi didasarkan bahwa materi tersebut harus:
a. Dipandang penting
b. Sesuai dengan kemampuan siswa
c. Yang sering digunakan dalam kehidupan sehari-hari
d. Frekuensi pemakaiannya luas.

\section{Metode Pengajaran Keterampilan Berbicara Bahasa Arab}

Dalam penagjaran keterampilan berbicara bahasa Arab ada beberapa metode yang dapat digunakan, diantaranya: ${ }^{7}$

a. Metode Muhadatsah

Pembelajaran muhadatsah memiliki tahapan yang perlu diperhatikan sehingga kemampuan bercakap secara perlahan mampu dicapai. Dalam penerapan memerlukan metode yang tepat sehingga arah dan tujuan yang dicapai terlaksana dengan baik. Ada beberapa metode pembelajaran kemampuan berbicara dengan tetap memperhatikan jenjang kemampuannya.

b. Latihan asosiasi dan identifikasi

Latihan ini dimaksudkan untuk melatih spontanitas siswa dan kecepatannya dalam mengidentifikasi dan mengasosiasikan makna ujaran yang didengarnya. Bentuk latihan antara lain :

1) Guru menyebut satu kata, siswa menyebut kata lain yang ada hubungannya dengan kata tersebut.

2) Guru menyebut satu kata, siswa menyebut kata lain yang tidak ada hubungannya dengan kata tersebut.

3) Guru menyebut satu kata kerja (fi'il), siswa menyebut pelaku yang cocok.

c. Latihan percakapan

Ada beberaa model-model latihan percakapan sebagai berikut:

1) Tanya jawab

\footnotetext{
${ }^{7}$ Mahmud Yunus, Metode Khusus Bahasa Arab, (Jakarta: PT. Hidakarya Agung, 1990), h. 68
} 
Guru mengajukan satu pertanyaan, siswa satu menjawab dengan satu kalimat, kemudian siswa satu bertanya dan siswa dua menjawab, kemudian siswa dua bertanya dan siswa tiga menjawab dan seterusnya.

2) Mengahafalkan model dialog

Guru memberikan satu model dialog secara tertulis untuk dihafalkan oleh siswa di rumah masing-masing. Pada minggu berikutnya secara berpasangan mereka diminta tampil di muka kelas untuk memperagakan dialog tersebut, tertapi mendramatisasikannya dengan memperhatikan segi-segi ekspresi, mimic, gerak-gerik, intonasi. Dialog-dialog harus disesuaikan dengan tingkat kemahiran siswa dan bersifat situasional yang diambil dari kehidupan sehari-hari. Misalnya rumah, sekolah, pasar dan sebagainya.

3) Percakapan terpimpin

Guru menentukan situasi atau konteksnya. Siswa diharapkan mengembangkan imajinasinya sendiri dalam percakapan dengan lawan bicaranya sesuai dengan munasabah yang telah ditentukan.

4) Percakapan bebas

Guru hanya menetapkan topic pembicaraan. Siswa diberi kesempatan melakukan percakapan mengenai topic tersebut secara bebas. Guru membuat beberapa kelompok siswa dan melakukan pengawasan terhadap masing-masing kelompok. Guru juga member perhatian khusus untuk beberapa siswa yang kurang mampu dan kelompok yang kurang bersemangat. ${ }^{8}$

\section{Pembelajaran Keterampilan Berbicara Berbasis PAIKEM}

Pendekatan PAIKEM meningkatkan kemauan siswa untuk berbicara dengan aktif, inovatif dan kreatif. Pendekatan ini sangat menunjang bagaimana sikap siswa untuk tidak takut salah atau minder dalam bercakap. Salah satu teknik yang tepat untuk diaplikasikan dengan pendekatan ini adalah field study. Tujuan teknik ini adalah memadukan pengalaman yang diperoleh di dalam kelas dengan pengalaman yang actual di lapangan. Selain itu kondisi sekolah dan potensi yang ada di sekolah sangat menunjang kemauan dan kemampuan para siswa untuk berbicara.

Contoh: Jika di sekolah ada kanti sekolah, maka kantin sekolah bisa menjadi sumber percakapan tentang fi waktil istirohah.

8 Henry Guntur Tarigan, Berbicara Sebagai Suatu Keterampilan Berbahasa, (Bandung: Angkasa, 1981), h. 3 


\section{Media Pengajaran Keterampilan Berbicara Bahasa Arab}

Adapun media sederhana yang dapat digunakan dalam sebagai media pembelajaran keterampilan berbicara bahasa Arab adalah sebagai berikut: ${ }^{9}$

a. Kartu

Kartu pada dasarnya adalah kertas tebal berbentuk persegi panjang untuk berbagai keperluan. ${ }^{10}$ Diantara kartu yang dapat digunakan dalam pembelajaran keterampilan berbicara bahasa Arab, yaitu kartu kilat dan kartu peran.

b. Peta

Peta secara umum tersedia di setiap sekolah/madrasah. Karena itu ketersediaannya perlu diperhatikan oleh pengajar bahasa Arab. Jika pengajar bahasa Arab dapat menggunakan peta secara kreatif dalam pembelajaran bahasa Arab, maka pembelajaran Bahasa Arab tidak akan kosong dari media.

c. Bahan Otentik

Bahan/kartu otentik dalam pembelajaran bahasa Arab pada dasarnya harus berbahasa target. Meskipun demikian, jika tidak dapat diperoleh Bahan Otentik berbahasa target, dapat dibuat bahan otentik tiruan. Diantara contoh bahan otentik adalah kartu nama toko emas, kartu maktab/majmu'ah haji di madinah, kartu nama, dan kartu identitas. Kartu identitas dapat digunakan untuk melatih percakapan perdasarkan isi atau pesan yang terdapat dalam kartu tersebut. Begitu juga dengan brosur-brosur promosi minimarket atau supermarket dapat digunakan untuk melatih percakapan bahasa Arab.

\section{Evaluasi Pengajaran Keterampilan Berbicara Bahasa Arab}

Untuk melakukan evaluasi keterampilan berbicara bahasa Arab dapat dilakukan melalui beberapa tes sebagai berikut: ${ }^{11}$

a. Tes Pelafalan

Tes pelafalan seperti menirukan pelafalan, melafalkan tekanan dan intonasi, membaca nyaring teks yang sudah dihafal, menyempurnakan kalimat, menjawab pertanyaan sesuai sketsa, dan membaca bersuara.

b. Tes Praktek Struktur (qawaid) secara verbal

\footnotetext{
${ }^{9}$ Imam Asrori dan Moh. Ahsanuddin,Media Pembelajaran Bahasa Arab Dari Kartu Sederhana Sampai Web Penjelajah Dunia, (Malang: CV Bintang Sejahtera, 2016), hal. 33

${ }^{10}$ N.A. Ridwan, Kartu Kata dan Kartu Gambar sebagai media Pembelajaran Bahasa Arab di Madrasah Ibtidaiyah. Makalah disampaikan dalam Pelatihan Pembuatan dan Penggunaan Gambar dan Kartu Kata untuk Pembelajaran Bahasa Arab di Madrasah Ibtidaiyah, pada tanggal, 24-25 Juni 2006, (Malang: Jurusan Sastra Universitas Negeri Malang)

${ }_{11}$ Moh. Matsna HS dan Erta Mahyudin, Pengembangan Evaluasi dan Tes Bahasa Arab, (Tangerang Selatan: Alkitabah, 2012), h. 153-156
} 
Tes ini berupa mengubah kata atau kalimat, menghubungkan kalimat, saling bertanya jawab, mengubah kalimat pernyataan menjadi pertanyaan dan sebagainya

c. Tes Berbicara Menggunakan Rangsang Visual

Tes ini dapat berbentuk pertanyaan mengenai waktu, jarak, dan ukuran sesuai gambar, membaca angka, mendeskripsikan gambar, menarasikan aktivitas atau gerakan, serta menarasikan cerita bergambar.

d. Tes melalui wawancara dan diskusi

Tes ini ditandai dengan persiapan berupa daftar pertanyaan yang tersetruktur yang harus dijawab oleh siswa. Teknik ini biasanya dilakukan pada mereka yang telah memiliki kemampuan bahasa Arab yang dirasa sudah cukup memadai sehingga memungkinkan untuk mengungkapkan pikiran dan perasaannya.

e. Tes dengan Mengarang lisan

Untuk mengukur penguasaan siswa terhadap kosakata, pemilihan katakata yang tepat, tata kalimat, dan tata bunyi seprti nada, irama, dan alunan suara guru dapat meminta mereka untuk membuat karangan lisan.

f. Tes melalui Bercerita

Guru mula-mula memberikan beberapa topic cerita yang pernah disampaikan lalu meminta siswa untuk memilih salah satu topic dan menceritakan kembali di depan kelas tanpa teks.

g. Tes dengan berpidato

Pidato juga dapat dikategorikan sebagai salah satu bentuk tes untuk mengukur kemampuan berbicara siswa. Dalam konteksn pengajaran dan atau penyelenggaraan tes berbicara, tugas pidato dapat berwujud permainan simulasi, misalnya siswa bersimulasi sebagai kepala sekolah yang berpidato dalam upacara bendera, menyambut tahun ajaran baru, memperingati hari-hari besar nasional, atau hari-hari besar keagamaan.

\section{Pengajaran Keterampilan Berbicara Bahasa Inggris}

\section{Tujuan Pengajaran Keterampilan Berbicara Bahasa Inggris}

Menurut Ramlannarie, speaking merupakan proses berpikir dan bernalar agar pembicaraan seseorang dapat diterima dan dipahami dengan baik oleh orang lain atau penyimak. ${ }^{12}$

Seperti halnya mempelajari bahasa ibu, anak-anak lebih banyak mendengarkan disertai respon fisik seperti menjangkau, merampas, menggerakkan, melihat dan seterusnya sebelum mereka berbicara.

\footnotetext{
${ }^{12}$ Ramlannarie, Pembelajaran Berbicara Dengan Model Pembelajaran Debat. 2011. h. 88
} 
Pembelajaran Speaking adalah kegiatan menyampaikan suatu pesan atau informasi kepada orang lain dalam bentuk lisan. Pembelajaran ini akan lebih berhasil apabila seseorang sering melakukan latihan dalam pengucapan sebelum mereka menggunakan bahasa.

Tujuan pembelajaran keterampilan berbicara bahasa Inggris (speaking) adalah agar para siswa dapat berpartisipasi dalam percakapan singkat, memberi dan menjawab pertanyaan, menemukan cara untuk menyampaikan maksud, mengumpulkan informasi dari yang lain, dan masih banyak lagi. ${ }^{13}$

\section{Materi Pengajaran Keterampilan Berbicara Bahasa Inggris}

Dalam menyusun materi pelajaran keterampilan bahasa Inggris harus selalu mengacu pada tujuan yang hendak dicapai sehingga dalam penyusunan materi harus ada seleksi, gradasi dan organisasi materi.

Seleksi dimaksudkan untuk menentukan materi apa yang sesuai dengan tujuan yang akan dicapai, gradasi dimaksudkan bahwa materi harus disampaikan secara bertahap, sedangkan organisasi materi adalah menentukan luas dan susunan bahan, kontiunitas serta bahan yang akan di sajikan.

\section{Metode Pengajaran Keterampilan Berbicara Bahasa Inggris}

Adapun metode yang bisa diterapkan dalam mengajarkan keterampilan berbicara bahasa Inggris adalah sebagai berikut: ${ }^{14}$

a. Ask and Answer

Siswa diminta melakukan Tanya jawab. Prosesnya, mintalah siswa mencatat beberapa pertanyaan interview kalau perlu dihapalkan. Kemudian bebaskan siswa bertanya kepada teman dikelasnya. Sesuaikan pertanyaan dengan tema. Missal tema Personal Identity, Shopping List, Map dan lain-lain. Untuk mengecek apakah siswa melakukan tugas tersebut, mintalah mereka mencatat yang harus dilaporkan kepada guru setelah proses pembelajaran berakhir. Guru hanya memonitor siswa dan memberikan waktu untuk siswa melakukan Tanya jawab.

b. Describe and Draw

Siswa dibuat berpasangan. Siswa A mempunyai gambar yang tak diketahui oleh siswa B, begitu pula sebaliknya. Siswa A menerangkan gambar yang ia punyai dan siswa B menggambar sesuai keterangan siswa A. setelah siswa A selesai, ganti siswa B menerangkan gambarnya. Mintalah mereka membandingkan gambarnya dan member nilai sesuai selera mereka

${ }^{13}$ Brown, Characteristic of Successful Speaking Activities,(New York: Cambridge University Press, 2010), h. 113

${ }^{14}$ Marry J. Spratt, Alan Pulverness and Melanie Williams, The Teaching Knowlidge Test Course, (New York: Cambridge University Press), h. 54 


\section{c. Discussion}

Tentukan sebuah topic dan mintalah siswa secara berkelompok mendiskusikan topic sesuai gambar. Ini cocok diterapkan bagi intermediate and advance learners.

d. Guessing

Guru atau beberapa murid mempunyai sebuah informasi yang harus ditebak oleh siswa atau kelompok lain dengan menanyakan dalam bahasa Inggris.

\section{e. Rememberring}

Siswa menutup mata dan mengingat gambar, misalnya benda di dalam kelas atau letak tempat-tempat. Cara ini efektif untuk mengasah daya ingat dan meminimalisir lupa terhadap kosakata.

f. Miming

Seorang siswa mempraktekkan mimic tertentu semisal perasaan, melakukan suatu kegiatan dan lainnya. Sementara siswa yang lain menebak.

g. Ordering

Siswa diminta mengurutkan sesuatu dengan menanyakan dimana letaknya sampai menemukan tempat yang sesuai.

h. Completing A Form/Questionnaire

Siswa bertanya jawab, atau menyediakan informasi tertentu untuk menyempurnakan sebuah formulir atau kuis. Cara ini efektif diterapkan pada pelajaran berhubungan dengan identitas, semisal formulir lowongan kerja, pengisian paspor dan lainnya.

i. Role Play

Metode ini cocok untuk pembelajar yang telah mencapai level intermediate dan di atasnya. Siswa mempraktekkan sebuah situasi semisal di kantor polisi, pengadilan, drama, dan lain-lain. Siswa hanya diminta menggunakan ungkapan-ungkapan yang pernah dipelajari atau menggunakan bantuan kartu. Guru bertindak member arahan dan memonitoring kegiatan.

\section{j. Information Gap Task}

Mazrozikin menyatakan bahwa teknik information gap merupakan gabungan dari teknik yang mana (which face)?, pura-pura lupa (loss of memory), dan membagi informasi (shared information). Kegiatan ini adalah salah satu bentuk dari banyak kegiatan komunikatif. ${ }^{15}$

k. Total Physical Response (TPR)

\footnotetext{
${ }^{15}$ Mazrozikin. 2010. Kerangka Model Pembelajaran Interaktif http://masrozikin.wordpress.com/kerangka-model-pembelajaran-interaktif. 30 September 2017
} 
Karakteristik proses belajar mengajar metode TPR ini adalah tahap pertama dari pelajaran adalah model. Instruktur memberikan perintah pada beberapa siswa kemudian guru ikut melakukan apa yang diperintahkannya bersama siswa tadi. Pada tahap kedua siswa mendemontrasikan bahwa mereka mampu dan paham perintah dengan mengerjakannya sendiri, siswa lainnya yang mengamati juga mempunyai kesempatan untuk mendemonstrasikan pemahaman mereka.

Kemudian guru kembali mengkombinasikan elemen perintahnya agar siswa dapat mengembangkan fleksibilitasnya dalam memahami ungkapan yang tidak familier. Perintah yang akan dikerjakan siswa biasanya yang lucu-lucu.

Setelah belajar, agar dapat merespons perintah secara lisan, siswa belajar untuk membaca dan menulisnya ketika siswa siap untuk berbicara, mereka menjadi orang yang melakukan perintah. Setelah siswa mulai berbicara, kegiatan ditambah dengan permainan. ${ }^{16}$

\section{Community Language Learning}

Karakteristik dari proses belajar mengajar dari metode CLL ini adalah siswa secara tipikal memiliki sebuah percakapan yang menggunakan bahasa asal mereka. Guru membantu mereka untuk mengekspresikan apa yang ingin mereka katakan dengan memberi sepotong terjemahan bahasa target. Potongan tersebut direkam, kemudian diputar, suaranya seperti suara percakapan yang berubahubah, kemudian dibuat transkip percakapan dan terjemahan dengan bahasa target ditulis dibawahnya. Transkip percakapan akan banyak membantu siswa. Beragam kegiatan dilakukan seperti (ujian grammar, pronounciation atau membuat kalimat baru dengan kata-kata dari transkip) agar siswa dapat lebih menjelajahi bahasa mereka, selama pelajaran siswa diajak untuk mengungkapkan bagaimana mereka merasakan dan sebaliknya guru memahami mereka. ${ }^{17}$

\section{Media Pengajaran Keterampilan Berbicara Bahasa Inggris}

Diantara media pembelajaran keterampilan bahasa Inggris yang dapat digunakan dalam pembelajaran speaking adalah sebagai berikut: ${ }^{18}$ a. Video

Video merupakan salah satu media yang dapat digunakan dalam pembelajaran bahasa Inggris. Video merupakan media yang ampuh bagi para pembelajar saat mempelajari bahasa Inggris terutama ketika mereka sedang

${ }^{16}$ Diane Larsen-Freeman, Techniques And Principles In Language Teaching, second edition, (Oxford University Press, New York, 2000), h. 107

${ }^{17}$ Jack C. Richard and Thoedore S Rogers, Approaches and Methods in Language Teaching A description and analysis (Cambridge University Press, New York,1972) h. 9-10 6 June 1996. Hal. 8

${ }^{18}$ Paul Nation, The Four Strands of Language Course. TESOL in context volume 
mempelajari berbagai macam ungkapan atau ekspresi, seperti ungkapan memuji, berterima kasih, mengakui dan mengingkari fakta, mengundang seseorang dan sebagainya.

b. Games

Games juga merupakan media yang ampuh karena dengan melakukan sebuah permainan yang mengandung pembelajaran, siswa akan lebih mudah menerima dan mengerti karena para siswa akan belajar dengan keadaan dibawah sadar, atau dengan kata lain para siswa tidak sadar mereka sedang mempelajari sesuatu ketika sedang bermain games.

c. Flashcards

Media ini biasanya berisikan gambar-gambar umum seperti berbagai jenis hewan, pakaian, buah-buahan, syaur-sayuran, dan sebagainya. Mereka akan mudah mempelajari kosakata ketika ada gambar yang diperlihatakan kepada mereka.

d. Realia

Realia merupakan sebuah benda nyata yang dibawa oleh seorang guru ke dalam kelas untuk mengajarkan sesuatu yang berhubungan dengan benda tersebut.

\section{Evaluasi Pengajaran Keterampilan Berbicara Bahasa Inggris}

Evaluasi keterampilan berbicara bahasa Inggris dapat dilakukan melalui dua kelompok tes, yaitu: ${ }^{19}$

a. Tes Berbicara Langsung (Direct Oral Performance Testing)

Tes ini menuntut siswa untuk menemukan, membatasi, mengembangkan dan mengorganisasikan gagasannya secara terpadu dan utuh kemudian mewujudkannya dalam kegiatan berbicara. Tes berbicara langsung ini berupa tugas berbicara dengan stimulus tertentu. Misalnya, berbicara dengan diberikan tema tertentu, berbicara berdasarkan gambar seri yang disediakan, berbicara berdasarkan buku, atau berbicara berdasarkan hasil pengamatan objek/kegiatan tertentu.

b. Tes Berbicara Tidak Langsung (Indirect Oral Performance Testing)

Tes berbicara tidak langsung hanya dapat mengukur kompetensi siswa dengan menggunakan kemampuan lisan, intonasi, jeda, nada, dan kinesik siswa.

\section{Pelaksanaan Pengajaran Muhadatsah di STAIN Curup}

Melalui penelitian yang telah dilaksanakan oleh peneliti terhadap pengajaran Muhadatsah di STAIN curup, baik melalui observasi maupun wawancara, maka peneliti memperoleh hasil penelitian berupa data-data dan informasi-informasi terkait pengajaran Muhadatsah sebagai berikut:

${ }^{19}$ Shihabuddin, Evaluasi Pengajaran Bahasa, (Bandung: UPI), h. 34 


\section{Tujuan}

Mata kuliah Muhadatsah diajarkan oleh Ustadz M. Arif Mustofa, M.Pd pada semester III, IV dan V yaitu mata kuliah Muhadatsah I, Muhadatsah II, dan Muhadatsah III. Berhubung pada saat penelitian ini dilaksanakan adalah pada semester ganjil, jadi objek yang menjadi fokus peneliti dalam penelitian ini adalah semester III dan V yaitu Muhadatsah I dan Muhadatsah III.

Mata kuliah Muhadatsah I adalah mata kuliah dasar dalam berbicara bahasa Arab. Adapun tujuan dari pembelajaran Muhadatsah I ini adalah agar mahasiswa mengenal ungkapan-ungkapan bahasa Arab sederhana dan mampu mengaplikasikannya dalam bentuk percakapan yang sederhana pula. Sedangkan mata kuliah Muhadatsah III merupakan mata kuliah lanjutan dan tahapan lebih tinggi dari mata kuliah Muhadatsah I dan Muhadatsah II. Tujuan dari pengajaran Muhadatsah III ini adalah untuk mengembangkan kemampuan berbicara bahasa Arab mahasiswa sehingga mampu menerapkannya dalam komunikasi yang lebih kompleks.

\section{Materi}

Adapun materi yang digunakan dalam mata kuliah Muhadatsah I adalah ungkapan-ungkapan sederhana yang diambil dari buku Arabiya Baina Yadaik.

Sedangkan materi yang digunakan untuk Muhadatsah III yaitu dibebaskan kepada mahasiswa untuk menentukan. Kebanyakan dari mereka juga mengambil Qawaid yang terdapat dalam buku Arabiya Baina Yadaik sebagai materi yang akan mereka gunakan dalam praktek mengajar berbahasa Arab didepan kelas.

\section{Metode}

Metode yang digunakan dalam mengajarkan Muhadatsah I berupa Percakapan Terpimpin yaitu dosen menentukan situasi atau konteksnya dengan mengambil ungkapan-ungkapan bahasa Arab sederhana yang terdapat dalam buku Arabiya Baina Yadaik, lalu percakapan tersebut ditulis di papan tulis sehingga semua mahasiswa melihat dan memahami dengan jelas bacaan dan maksud dari ungkapan tersebut. Kemudian mahasiswa diharapkan mengembangkan imajinasinya sendiri dengan memasukkan ungkapan-ungkapan sederhana tersebut ke dalam bentuk percakapan yang mereka buat sendiri dengan lawan bicaranya di depan kelas sesuai dengan munasabah yang telah ditentukan.

Selain Percakapan Terpimpin, pada sebagian tatap muka perkuliahan mahasiswa juga diminta untuk membuat makalah berbahasa Arab yang kemudian akan diminta untuk mempresentasikan dan mendiskusikan isi makalah tersebut juga dengan bahasa Arab. 
Sedangkan metode yang digunakan oleh dosen dalam mengajarkan Muhadatsah III adalah dengan mengistruksikan mahasiswa untuk menyiapkan materi kemudian meminta mereka untuk mengajar dihadapan teman-temannya di depan kelas dengan menggunakan bahasa Arab mulai dari pengantar, memberi materi, menjawab pertanyaan yang dilontarkan oleh mahasiswa yang lain juga menggunakan bahasa Arab hingga menutup perkuliahan.

Setelah selesai dari latihan percakapan, presentasi dan diskusi, serta mengajar dengan menggunakan bahasa Arab di depan kelas, dilanjutkan dengan komentar dari dosen pengampu berupa koreksi kesalahan yang dilakukan oleh mahasiswa baik dari segi pelafalan, intonasi, maupun makna bahasa yang digunakan oleh mahasiswa.

Kegiatan seperti ini dilakukan untuk seluruh pertemuan dalam mata kuliah Muhadatsah III. Semua mahasiswa semester V mendapatkan kesempatan untuk mengajar di depan kelas menggunakan bahasa Arab.

\section{Media}

Untuk media yang digunakan dalam pengajaran Muhadatsah I, dosen hanya menggunakan In Focus dalam memberikan ungkapan-ungkapan bahasa Arab kepada mahasiswa untuk dipahami sebelum mempraktikkannya dalam bentuk percakapan.

Untuk Muhadatsah III, dosen tidak menggunakan banyak media, tetapi hanya papan tulis ketika mengoreksi bahasa Arab mahasiswa, dosen menulisnya di papan tulis agar dapat diingat dan dicatat oleh mahasiswa seluruhnya. Sedangkan media yang digunakan oleh mahasiswa ketika praktik mengajar bahasa Arab di depan kelas beragam, diantaranya ada yang menggunakan In Focus dan ada juga yang menggunakan media kartu.

\section{Evaluasi}

Evaluasi dalam mata kuliah Muhadatsah I dilakukan dalam bentuk Ujian Tengah Semester dan Ujian Akhir Semester yaitu dengan meminta mahasiswa untuk membuat percakapan dengan tema yang telah ditentukan oleh dosen pengampu.

Begitu juga halnya dalam mata kuliah Muhadatsah III, dilaksanakan dalam bentuk Ujian Tengah Semester dan Ujian Akhir Semester. Pada ujian, dosen akan menentukan tema yang harus dibuat oleh mahasiswa. Mahasiswa diberi kesempatan untuk memahami tema tersebut dalam waktu 5 menit. Kemudian mahasiswa diminta menulis percakapan dengan tema tersebut. 


\section{Pelaksanaan Pengajaran Speaking di STAIN Curup}

Melalui penelitian yang telah dilaksanakan oleh peneliti terhadap pengajaran Speaking di STAIN curup, baik melalui observasi maupun wawancara, maka peneliti memperoleh hasil penelitian berupa data-data dan informasi-informasi terkait pengajaran Muhadatsah sebagai berikut:

\section{Tujuan}

Mata kuliah Speaking diajarkan pada semester II, III, IV, dan V, yaitu mata kuliah Speaking I, Speaking II, dan Speaking III, dan Speaking IV. Berhubung pada saat penelitian ini dilaksanakan adalah pada semester ganjil, jadi objek yang menjadi fokus peneliti dalam penelitian ini adalah semester III dan V yaitu Speaking II dan Speaking IV.

Mata kuliah Speaking II adalah mata kuliah tahapan kedua dalam pembelajaran berbicara bahasa Inggris, mata kuliah ini diajarkan oleh Mr. Paidi Gusmaliana, M.Pd. Adapun tujuan yang ingin dicapai dalam pembelajaran Speaking II ini adalah untuk memperlancar mahasiswa dalam berbicara bahasa Inggris, menguasai banyak kosa kata dan meningkatkan percaya diri (self confidence) berbicara bahasa Inggris, baik di dalam maupun diluar kelas perkuliahan.

Sedangkan mata kuliah Speaking IV diampu oleh Mr. Bayu Senjahari, M.Pd., M.Ed bertujuan untuk melatih mahasiswa berbicara bahasa Inggris secara spontan, lancar dan benar serta mampu mengembangkan kemampuan berbicara bahasa Inggris dalam berbagai keadaan dan konsep yang diinginkan.

\section{Materi}

Adapun materi yang digunakan dalam mata kuliah Speaking II adalah tidak ditentukan secara spesifik oleh dosen pengampu, akan tetapi diberi kebebasan kepada mahasiswa untuk mencari materi yang sesuai untuk mereka tampilkan dalam kelas perkuliahan Speaking II. Walaupun demikian adanya, kebanyakan dari mahasiswa lebih banyak mengambil sumber materi dari buku Communicative Speaking dan buku karangan dosen pengampu sendiri yang berjudul Cooperating Speaking into Classroom.

Sedangkan dalam Speaking IV dosen tidak menggunakan buku khusus sebagai rujukan dalam berbicara. Ketika diberi suatu tema, mahasiswa secara spontan berpikir, menulis, dan berbicara mengenai suatu tema tanpa mencontoh dari buku. Sebagian mereka ada yang memanfaatkan internet untuk mencari inspirasi atau ide mengenai tema yang dikehendaki oleh dosen. 


\section{Metode}

Dalam mengajarkan Speaking II terdapat dua kegiatan yang harus dilakukan oleh mahasiswa, yaitu sebagai berikut:.

Pertama, kegiatan luar kelas, pada kegiatan ini adalah dengan menginstruksikan kepada mahasiswa untuk melaksanakan kegiatan di luar kelas, yaitu ke Panti Asuhan, Sekolah-sekolah, Pos Polisi dan lain sebagainya. Pada kesempatan itu mahasiswa telah dibagi dalam kelompok-kelompok untuk melaksanakan kegiatan-kegiatan yang telah mereka rencanakan sebelumnya. Semua kegiatan yang berlangsung di tempat tersebut harus mereka dokumentasikan dalam bentuk foto ataupun video. Selain itu mereka juga membuat Talk. Show seperti acara ditelevisi yang didokumentasikan dalam bentuk video.

Kedua, kegiatan dalam kelas, sebelum berlangsungnya kegiatan di dalam kelas ini, dosen pengampu menjelaskan terlebih dahulu prosedur atau apa yang harus mereka lakukan didalam kelas, nanti ketika terjadi Tanya jawab, dosen menjelaskan bagaimana selayaknya bertanya dan menjawab dalam bahasa Inggris, begitu pula bagaimana seharusnya mempresentasikan materi dalam bahasa Inggris.

Selanjutnya yang harus dilakukan oleh mahasiswa pada tahapan kedua ini adalah mahasiswa diminta untuk mempresentasikan hasil kegiatan luar kelas yang telah mereka lakukan dengan menggunakan bahasa Inggris. Semua kejadian yang telah didokumentasikan harus diceritakan sedetail mungkin kepada mahasiswa lainnya. Disinilah nanti akan muncul metode diskusi. Ketika ada hal yang dianggap kurang jelas oleh mahasiswa lainnya mengenai kegiatan tersebut, maka mereka diberi kesempatan untuk bertanya, mengkrtik, memberi saran dan sebagainya yang sekiranya dapat meningkatkan kemampuan interaksi dengan bahasa Inggris mereka.

Selain mempresentasikan hasil program luar kelas, mahasiswa juga diminta untuk mempraktekkan drama di dalam kelas dengan tema mereka tentukan sendiri.

Sedangkan metode yang digunakan oleh dosen dalam mengajarkan Speaking IV adalah Direct Theme yaitu mahasiswa harus berbicara berdasarkan tema yang telah ditentukan oleh dosen. Metode ini diawali dengan pemberian tema oleh dosen kemudian meminta mahasiswa menyiapkan dalam bentuk tertulis selama 15 menit mengenai apa yang akan ia sampaikan terkait tema yang telah ditentukan oleh dosen, mulai dari yang umum, lalu khusus dan disertai dengan contoh. Setelah 15 menit berlalu dan semua mahasiswa selesai menyiapkan. Kemudian mahasiswa diminta untuk mengacungkan tangan bagi yang ingin berbicara terlebih dahulu. Biasanya mahasiswa sangat berantusias untuk berbicara lebih awal dari teman-temannya yang lain. Kalaupun sekiranya 
tidak ada yang mengacungkan tangan untuk berbicara, maka dosen langsung berinisiatif untuk menunjuk mahasiswa satu persatu untuk langsung berbicara mengenai tema pada hari itu.

\section{Media}

Adapun media yang digunakan dalam pembelajaran Speaking II adalah sebagai berikut:

a. In focus, digunakan oleh dosen pengampu untuk menjelaskan mengenai tata cara presentasi dengan bahasa Inggris, begitu juga cara bertanya dan menanggapi pertanyaan yang benar dalam bahasa Inggris.

a. Video, digunakan oleh mahasiswa untuk mempresentasikan hasil kegiatan di luar kelas berupa Talk Show.

b. Poster, foto-foto kegiatan diluar kelas yang telah dilaksanakan oleh mahasiswa kemudian ditempel pada karton sehingga membentuk poster yang kemudian digunakan oleh mahasiswa untuk mempresentasikan kegiatan diluar kelas.

Sedangkan pada mata kuliah Speaking IV baik dosen atau mahasiswa tidak menggunakan media apapun dalam pembelajaran selain kadang-kadang menggunakan papan tulis untuk mengoreksi jika terdapat kesalahan bahasa Inggris yang diucapkan oleh mahasiswa dalam berbicara. Begitu pula halnya dengan mahasiswa ketika mereka diminta untuk berbicara bahasa Inggris mengenai suatu tema, mereka langsung berbicara tanpa menggunakan media khusus.

\section{Evaluasi}

Adapun evaluasi yang dilaksanakan dalam pembelajaran Speaking II terdiri dari Ujian Tengah Semester dan Ujian Akhir Semester. Pada Ujian Tengah Semester mahasiswa diminta untuk mementaskan drama berbahasa Inggris dengan tema tidak ditentukan oleh dosen tetapi diserahkan kepada mahasiswa untuk berkreasi menentukannya sendiri.

Berbeda dengan evaluasi pada Ujian Tengah Semester, pada Ujian Akhir Semester mahasiswa akan diberi pertanyaan langsung secara lisan oleh dosen pengampu mata kuliah Speaking II mengenai tema-tema yang sudah diajarkan sebelumnya. Ketika ujian berlangsung mahasiswa akan dipanggil satu persatu untuk ditanya.

Pada mata kuliah Speaking IV, Ujian Mid Semester dan Ujian Akhir Semester dilaksanakan tidak jauh berbeda dengan perkuliahan-perkuliahan 
seperti biasa yaitu dengan membagikan tema-tema yang berbeda kepada seluruh mahasiswa. Masing-masing mahasiswa mendapatkan satu tema. Kemudian diberi kesempatan 15 menit untuk mempersiapkan apa yang akan dibicarakan mengenai tema tersebut. Setelah waktu yang diberikan selesai, mahasiswa berbicara mulai dari hal yang umum hingga khusus disertai dengan contoh.

\section{Perbandingan Pengajaran Muhadatsah dan Speaking di STAIN Curup}

Berdasarkan data-data dan informasi yang telah diperoleh peneliti terkait pengajaran Muhadatsah dan pengajaran Speaking yang ada di STAIN Curup, maka peneliti melakukan analisis perbandingan dengan uraian sebagai berikut:

\section{Tujuan}

Tujuan pembelajaran merupakan hal pertama yang harus ditentukan. Dengan adanya tujuan yang jelas, maka akan mempermudah dalam menentukan dan memilih materi, metode, media dan evaluasi yang sesuai yang akan digunakan.

Tujuan pengajaran Muhadatsah adalah agar mahasiswa mengenal ungkapan-ungkapan dalam bahasa Arab mulai dari hal sederhana yang diaplikasikan dalam bentuk percakapan, hingga mengembangkannya sehingga mampu menerapkannya dalam komunikasi yang lebih kompleks.

Sedangkan tujuan pengajaran Speaking adalah untuk memperlancar mahasiswa dalam berbicara bahasa Inggris, menguasai banyak kosa kata dan meningkatkan percaya diri (self confidence) berbicara bahasa Inggris, baik di dalam maupun diluar kelas perkuliahan sehingga mampu berbicara bahasa Inggris dalam segala situasi dan konsep yang dikehendaki.

Pada dasarnya pengajaran dari kedua keterampilan berbicara baik bahasa Arab (Muhadatsah) maupun keterampilan berbicara bahasa Inggris (Speaking) sama-sama melatih kemampuan mahasiswa dalam menggunakan kedua bahasa tersebut di dalam komunikasi dan interaksi dengan lawan bicara baik itu mahasiswa, dosen, maupun dengan yang lainnya.

Pembelajaran Muhadatsah masih pada tahapan yang sederhana dan berlangsung hanya di kelas perkuliahan saja. Sedangkan pembelajaran Speaking sudah pada tahapan berbicara yang lebih tinggi dan berlangsung tidak hanya dikelas perkuliahan tetapi juga diluarnya. 


\section{Materi}

Materi pembelajaran Muhadatsah lebih kepada ungkapan-ungkapan dari buku Arabiya Baina Yadaik dalam praktek mengajar dengan menggunakan bahasa Arab didepan kelas. Sedangkan materi pembelajaran Speaking dari buku Communicative Speaking dan buku Coorperating Speaking into Classroom.

Dalam pengajaran keterampilan bahasa Arab dan keterampilan bahasa Inggris sama-sama menggunakan buku sebagai referensi dalam menentukan ungkapan-ungkapan bahasa asing (Arab atau Inggris) yang akan ditampilkan di dalam kelas perkuliahan. Akan tetapi disisi lain, dosen juga memberikan kebebasan kepada mahasiswa dalam mempraktekkan bahasa asing dengan menemukan ide-ide baru diluar buku referensi yang dijadikan rujukan. Selama tidak keluar dari tema yang telah ditentukan.

Buku yang digunakan sebagai referensi dalam pembelajaran Muhadatsah menggunakan buku karangan Dr. Abdurrahman bin Ibrahim Al-Fauzan dkk yang cukup lama keberdaannya dalam pembelajaran bahasa Arab, sedangkan pembelajaran Speaking menggunakan buku karangan dosen sendiri.

\section{Metode}

Metode yang digunakan dalam mengajarkan Muhadatsah diantaranya berupa:

1. Percakapan Terpimpin

Yang dimaksud dengan Percakapan Terpimpin dalam hal ini adalah dosen menentukan situasi atau konteks percakapan yang harus dilakukan oleh mahasiswa, dan mahasiswa diharapkan mengembangkan imajinasinya sendiri dengan menggunakan ungkapan-ungkapan sederhana yang telah diberitahu oleh dosen sebelumnya.

2. Makalah dan Diskusi

Dalam mata kuliah Muhadatsah, mahasiswa juga diminta untuk membuat makalah berbahasa Arab, lalu mempresentasikan dan mendiskusikan isi makalah tersebut dengan rekan mahasiswa lain. Semua kegiatan yang berlangsung selama perkuliahan adalah dengan menggunakan bahasa Arab. c. Latihan Mengajar

Mahasiswa diminta untuk mengajar dihadapan teman-temannya di depan kelas dengan menggunakan bahasa Arab mulai dari pengantar, memberi materi, 
menjawab pertanyaan yang dilontarkan oleh teman-temannya juga menggunakan bahasa Arab hingga menutup perkuliahan.

Sedangkan metode yang digunakan dalam mengajarkan Speaking diantaranya berupa:

a. Field Study

Pada kegiatan ini mahasiswa telah dibagi dalam kelompok dan diminta untuk melaksanakan kegiatan ke Panti Asuhan, Sekolah-sekolah, Pos Polisi dan lain sebagainya. Di tempat tersebut mereka melaksanakan kegiatan-kegiatan yang telah mereka rencanakan sebelumnya. Semua kegiatan yang berlangsung di tempat tersebut harus mereka dokumentasikan dalam bentuk foto ataupun video. Selain itu mereka juga membuat Talk. Show seperti acara ditelevisi yang didokumentasikan dalam bentuk video.

b. Discussion

Pada metode ini, mahasiswa diminta mempresentasikan foto dan video yang berisi dokumentasi kegiatan luar kelas yang telah mereka lakukan dengan menggunakan bahasa Inggris. Semua kejadian yang telah didokumentasikan harus diceritakan sedetail mungkin kepada mahasiswa lainnya. Ketika ada hal yang dianggap kurang jelas oleh mahasiswa lainnya mengenai kegiatan tersebut, maka mereka diberi kesempatan untuk bertanya, mengkrtik, memberi saran dan sebagainya yang sekiranya dapat meningkatkan kemampuan interaksi dengan bahasa Inggris mereka.

c. Role Play

Mahasiswa diminta untuk membuat sebuah drama dengan tema yang mereka tentukan sendiri. Kemudian mempraktikkan drama tersebut dengan menggunakan bahasa Inggris.

d. Direct Theme

Mahasiswa harus berbicara berdasarkan tema yang telah ditentukan oleh dosen. Mulai dari hal yang bersifat umum, lalu khusus dan disertai dengan contoh.

Pembelajaran Muhadatsah dan Speaking di STAIN Curup bersifat Student Centris, dimana dalam pembelajaran mahasiswa terlibat aktif dalam praktek berbahasa Arab dan Inggris. Keadaan seperti ini baik untuk melatih dan mengambangkan kemampuan dalam berbicara. Seperti yang dikatakan oleh Mazhab Komunikatif bahwa pengajaran berbicara akan lebih mudah bila 
pembelajar terlibat dalam upaya-upaya berkomunikasi. Peran pengajar hanyalah sebagai fasilitator murni artinya hanyalah meyakinkan bahwa aktifitas pembelajaran berada dalam situasi dan proses yang alami.

Seperti halnya dalam metode drama (Role Play) dan Field Study dalam pembelajaran Speaking, bersifat tidak formal dan sedikit santai namun tetap terarah sehingga menyenangkan bagi mahasiswa dan tidak membosankan. Begitu juga pada metode Makalah dan Discussion, Direct Theme, Percakapan Terpimpin dan Latihan Mengajar pada pembelajaran Muhadatsah dan Speaking, semua metode tersebut tidak terpaku pada teks bacaan sehingga mahasiswa lebih bebas mengungkapkan pendapat.

Dengan menyuguhkan metode yang bervariasi maka pembelajaran tidak akan membosankan bagi mahasiswa.

Pembelajaran Muhadatsah menggunakan metode yang dalam pelaksanaannya hanya berlangsung di dalam kelas perkuliahan, sedangkan pembelajaran Spekaing menggunakan metode yang pelaksanaannya berlangsung diluar dan di dalam kelas perkuliahan.

\section{Media}

Agar pembelajaran Muhadatsah dan Speaking dapat terlaksana dengan efektif dan efisien, maka digunakanlah media dalam pembelajarannya. Dalam pembelajaran Muhadatsah tidak hanya media papan tulis, tapi dosen juga memanfaatkan In Focus dalam memberikan ungkapan-ungkapan bahasa Arab yang baru kepada mahasiswa. Selain itu dalam kelas perkuliahan mahasiswa juga menggunakan kartu sebagai media menyampaikan materi kepada mahasiswa yang lainnya.

Sama halnya dengan pengajaran Muhadastah, dalam pengajaran Speaking dosen juga menggunakan In Focus dalam menyampaikan tata cara presentasi dengan bahasa Inggris, begitu juga cara bertanya dan menanggapi pertanyaan yang benar dalam bahasa Inggris. Sedangkan mahasiswa sudah menggunakan video dan poster dalam mempresentasikan materi kepada mahasiswa yang lainnya.

Baik dalam pengajaran Muhadatsah maupun pengajaran Speaking, dosen sama-sama menggunakan media In Focus. Dalam pembelajaran Speaking juga menggunakan media berbasis komputer lainnya, seperti video. Sedangkan dalam 
pembelajaran Muhadatsah mahasiswa hanya memanfaatkan media sederhana seperti kartu.

Jika dilihat dari jenis-jenis media pembelajaran maka dapat disimpulkan bahwa dalam pembelajaran Muhadatsah hanya memanfaatkan media audio, seperti In focus, papan tulis dan kartu. Sedangkan dalam pembelajaran Speaking selain media audio juga menggunakan media audio-visual seperti video.

\section{Evaluasi}

Evaluasi dilaksanakan guna untuk mengetahui tingkat pemahaman mahasiswa terhadap materi yang telah diberikan selama proses perkuliahan berlangsung, baik itu berupa penguasaan kosa kata maupun ungkapan-ungkapan yang biasa digunakan dalam berkomunikasi. Evaluasi juga dilakukan untuk mengetahui kemampuan mahasiswa dalam berkomunikasi dengan menggunakan bahasa Arab ataupun bahasa Inggris. Evaluasi yang dilaksanakan adalah dalam bentuk tes lisan baik berupa tes formatif maupun tes sumatif.

Tes formatif dilaksanakan dilaksanakan setelah serangkaian pembelajaran diterima oleh mahasiswa. Tes formatif biasa dalam penelitian ini dikenal dengan Ujian Tengah Semester.

Adapun tes formatif yang dilaksanakan dalam pembelajaran Muhadatsah adalah membuat percakapan dengan tema yang telah ditentukan oleh dosen secara tertulis. Sedangkan dalam pembelajaran Speaking adalah tes kemampuan berbicara bahasa Inggris melalui Role Play dan Direct Theme.

Kemudian tes sumatif atau Ujian Akhir Semester pada mata kuliah Muhadatsah sama halnya dengan pelaksanaan Ujian Tengah Semester, sedangkan pada mata kuliah Speaking berbeda dengan evaluasi pada Ujian Tengah Semester, pada Ujian Akhir Semester mahasiswa akan dites secara lisan oleh dosen mengenai tema-tema yang sudah diajarkan sebelumnya.

Tes kemampuan berbicara sudah seharusnya yang dievaluasi adalah kemampuan berbicara mahasiswa bukan menulis. Seperti dalam evaluasi Muhadatsah, sedikit dipertanyakan dengan keberadaan tes dalam bentuk menulis percakapan dengan tema yang telah ditentukan oleh dosen.

Dengan demikian secara keseluruhan dapat dilihat bahwa pengajaran Muhadatsah dan Speaking sebagai pengajaran keterampilan berbicara bahasa Arab dan Inggris lebih ditekankan para proses pembelajarannya yaitu 
pembelajaran yang terjadi selama 14 kali tatap muka dimana mahasiswa berbahasa aktif dalam pembelajaran dan bukan menekankan sepenuhnya pada evaluasi.

\section{Penutup}

Pengajaran keterampilan berbicara bahasa Arab (Muhadatsah) di STAIN Curup memiliki tujuan untuk mengenalkan ungkapan-ungkapan sederahana dalam bentuk percakapan bahasa Arab kepada mahasiswa dan mampu mengembangkan serta menerapkannya dalam komunikasi yang lebih kompleks. Untuk mencapai hal tersebut tidak lepas dari latihan-latihan berbicara. Hal ini dapat dilihat pada pemberian materi yang secara keseluruhan diberikan kebebasan kepada mahasiswa untuk menentukan agar tidak membatasi kreativitas bahasa yang mereka gunakan disamping penggunaan buku Arabiya Baina Yadaik. Metode percakapan terpimpin, makalah dan diskusi, serta latihan mengajar yang disuguhkan semuanya dinilai dapat melatih berbicara bahasa Arab secara aktif. Media yang digunakan hanya media visual dan evaluasi berupa menulis percakapan.

Pengajaran keterampilan berbicara bahasa Inggris (Speaking) di STAIN Curup memiliki tujuan untuk memperlancar dalam berbicara bahasa Inggris, menguasai banyak kosa kata dan meningkatkan percaya diri (self confidence) berbicara bahasa Inggris, baik di dalam maupun diluar kelas perkuliahan sehingga mampu berbicara bahasa Inggris dalam segala situasi dan konsep yang dikehendaki. Pada pelaksanaannya pemberian materi yang secara keseluruhan juga diberikan kebebasan kepada mahasiswa untuk menentukan dan menggunakan buku Communicative Speaking dan buku Coorporating Speaking into Classroom. Dosen juga menggunakan metode yang bervariasi seperti Field Study, Discussion, Role Play dan Direct Theme. Dalam media pembelajaran selain media audio, juga menggunakan media audio-visual seperti video. Evaluasi yang diberikan dalam bentuk evaluasi formatif (Role Play dan Direct Theme) dan evaluasi sumatif (Interview).

Pengajaran Muhadatsah dan pengajaran Speaking sama-sama melatih kemampuan mahasiswa dalam menggunakan bahasa-bahasa tersebut di dalam komunikasi dan interaksi dengan lawan bicara. Dalam pengajaran tidak hanya menggunakan buku sebagai referensi tapi juga memberikan kebebasan kepada mahasiswa dalam mempraktekkan bahasa asing dengan menemukan ide-ide baru 
diluar buku referensi yang dijadikan rujukan. Pembelajaran Muhadatsah dan Speaking di STAIN Curup bersifat Student Centris, dengan menyuguhkan metode yang bervariasi. Dalam pembelajaran Muhadatsah hanya memanfaatkan media audio, sedangkan dalam pembelajaran Speaking selain media audio juga menggunakan media audio-visual. Secara keseluruhan dapat dilihat bahwa pengajaran Muhadatsah dan Speaking sebagai pengajaran keterampilan berbicara bahasa Arab dan Inggris lebih ditekankan para proses pembelajarannya yaitu pembelajaran yang terjadi selama 12 kali tatap muka dimana mahasiswa berbahasa aktif dalam pembelajaran dan bukan menekankan sepenuhnya pada evaluasi. 


\section{Daftar Kepustakaan}

Anshor. 2009. Pengajaran Bahasa Arab. Yogyakarka : Sukses offset

Asrori, Imam dan Ahsanuddin Moh. 2016. Media Pembelajaran Babasa Arab Dari Kartu Sederhana Sampai Web Penjelajah Dunia, Malang: CV Bintang Sejahtera

Brown. 2010. Characteristic of Successful Speaking Activities, New York: Cambridge University Press

Dahlan, Djuwairiah. 1992. Metode Belajar Mengajar Bahasa Arab, Surabaya: AlIkhlas

Diane Larsen-Freeman. 2000. Techniques And Principles In Language Teaching, second edition, Oxford University Press, New York, 2000

Djamarah, Syaiful Bahri dan Zain, Aswan. 2006. Strategi Belajar Mengajar, Jakarta: Rineka Cipta

Effendy, Ahmad Fuad. 2009. Metodologi Pengajaran Bahasa Arab, Malang : Misykat Izzan, Ahmad. 2007. Metodologi Pembelajaran Babasa Arab, Bandung: Humaniora Jack C. Richard and Thoedore S Rogers, Approaches and Methods in Language Teacbing A description and analysis, Cambridge University Press, New York,1972

Marry J. Spratt, Alan Pulverness and Melanie Williams, The Teaching Knowlidge Test Course, New York: Cambridge University Press

Matsna, Moh dan Mahyudin, Erta. 2012. Pengembangan Evaluasi dan Tes Babasa Arab. (Tangerang Selatan: Alkitabah

Mazrozikin. 2010. Kerangka Model Pembelajaran Interaktif http://masrozikin.wordpress.com/kerangka-model-pembelajaraninteraktif. 30 September 2017

Mukti. 1998. Pembinaan Kemampuan Berbicara Bahasa, Jakarta : Erlangga

Nation, Paul. The Four Strands of Language Course. TESOL in context volume 6 June 1996.

Ramlannarie. 2011. Pembelajaran Berbicara Dengan Model Pembelajaran Debat.

Ridwan, N.A. Kartu Kata dan Kartu Gambar sebagai media Pembelajaran Bahasa Arab di Madrasah Ibtidaiyah. Makalah disampaikan dalam Pelatiban Pembuatan dan Penggunaan Gambar dan Kartu Kata untuke Pembelajaran Bahasa Arab di Madrasah Ibtidaiyah, pada tanggal, 24-25 Juni 2006, Malang: Jurusan Sastra Universitas Negeri Malang

Shihabuddin. Evaluasi Pengajaran Bahasa, Bandung: UPI

Tarigan, Henry Guntur. 1981. Berbicara Sebagai Suatu Keterampilan Berbahasa, Bandung: Angkasa

Yunus, Mahmud. 1990. Metode Khusus Bahasa Arab, Jakarta: PT. Hidakarya Agung 